\title{
Initial production and quality of camu-camu fruits under organic and mineral fertilization ${ }^{1}$
}

\author{
Carlos Enrique Daniel Lopez Pinto², Juan Daniel Villacis Fajardo ${ }^{3}$, \\ Paulo Sérgio Taube ${ }^{4}$, José Augusto Amorim Silva do Sacramento ${ }^{4}$, Emerson Cristi de Barros ${ }^{5}$
}

\section{ABSTRACT}

Camu-camu [Myrciaria dubia (Kunth) McVaugh] is a native plant of the Amazon basin floodplains that is facing a domestication process in dry land. This study aimed to evaluate, qualitatively and quantitatively, camu-camu fruits obtained at the first harvest, in dry land areas, under mineral and organic fertilization. The experimental design was randomized blocks, with 10 treatments and 4 replications. Each experimental plot consisted of 4 lines with 5 holes $\left(3\right.$ plants hole $\left.{ }^{-1}\right)$. Fertilization with organic residues (filter cake and compost + filter cake) every four months provided a higher fruit yield (326 g plant ${ }^{-1}$ ). However, the yield was lower when mineral fertilization or its combination with organic matter $\left(76 \pm 40\right.$ g plant $\left.^{-1}\right)$ was used. Fertilization with filter cake + compost increased the fruit weight $(8.91 \mathrm{~g})$ and size $(2.47 \mathrm{~cm}$ in diameter and $2.30 \mathrm{~cm}$ in length). The mineral and organic fertilization did not influence the chemical characteristics of the camu-camu fruits.

KEYWORDS: Myrciaria dubia, macro and micronutrients, ascorbic acid, fruit biometry.

\section{INTRODUCTION}

Camu-camu [Myrciaria dubia (Kunth) Mc Vaugh] is a fruit tree that occurs in humid tropical climates, being naturally found in banks of rivers, lakes, floodplains and the flooded Amazon rainforest, in the following countries: Peru, Colombia, Venezuela and Brazil (Maeda et al. 2007, Hernández et al. 2011, Yuyama \& Valente 2011). Its fruits contain high levels of ascorbic acid, which can be as high as 7,355 mg

\section{RESUMO}

Produção inicial e qualidade de frutos de camu-camu sob fertilização orgânica e mineral

Camu-camu [Myrciaria dubia (Kunth) McVaugh] é uma planta nativa das planícies inundáveis da bacia amazônica que está em processo de domesticação em áreas de terra firme. Objetivou-se avaliar, qualitativa e quantitativamente, frutos de camu-camu obtidos na primeira produção, em áreas de terra firme, sob adubação mineral e orgânica. O delineamento experimental foi em blocos casualizados, com 10 tratamentos e 4 repetições. Cada parcela experimental foi composta por 4 linhas de 5 covas ( 3 plantas cova ${ }^{-1}$ ). A adubação com resíduos orgânicos (torta de filtro e composto + torta de filtro) a cada quatro meses proporcionou maior produção de frutos $\left(326 \mathrm{~g} \mathrm{planta}^{-1}\right)$. No entanto, a produção foi menor quando se utilizou fertilização mineral ou a combinação desta com matéria orgânica (76 $\pm 40 \mathrm{~g}$ planta $\left.^{-1}\right)$. A fertilização com torta de filtro + composto aumentou o peso $(8,91 \mathrm{~g})$ e o tamanho $(2,47 \mathrm{~cm}$ de diâmetro e $2,30 \mathrm{~cm}$ de comprimento) de fruto. A adubação mineral e orgânica não influenciaram nas características químicas dos frutos de camu-camu.

PALAVRAS-CHAVE: Myrciaria dubia, macro e micronutrientes, ácido ascórbico, biometria de frutos.

$100 \mathrm{~g}^{-1}$ of pulp (Yuyama \& Valente 2011, Chagas et al. 2015). This attribute has aroused consumer interest in its consumption, in products such as concentrated drinks and vitamins (Viégas et al. 2004, Penn Junior 2006).

Camu-camu is being domesticated for cultivation in non-flooded areas, since, in its normal environment, the fruit production is limited by the periodic flooding of the areas where it is found, resulting in one crop per year (Pinedo Panduro et al.

1. Received: Oct. 18, 2019. Accepted: Mar. 04, 2020. Published: Apr. 27, 2020. DOI: 10.1590/1983-40632020v5060821.

2. Empresa Brasileira de Pesquisa Agropecuária (Embrapa Amazônia Ocidental), Setor de Melhoramento Genético de Plantas,

Manaus, AM, Brasil. E-mail/ORCID: dalopi81@hotmail.com/0000-0002-5918-6108.

3. Universidade do Estado do Amapá, Campus Território dos Lagos, Macapá, AP, Brasil. E-mail/ORCID: davifa2840@gmail.com/0000-0002-6719-3017.

4. Universidade Federal do Oeste do Pará, Instituto de Biodiversidade e Florestas, Santarém, PA, Brasil.

E-mail/ORCID: pstjunior@yahoo.com.br/0000-0001-5786-7615, jassacramento@yahoo.com.br/0000-0002-8839-2189.

5. Universidade Federal de Viçosa, Departamento de Engenharia Agrícola, Viçosa, MG, Brasil. E-mail/ORCID: emersoncristi@gmail.com/0000-0002-9044-7994. 
2011, Pinto et al. 2013). In addition, due to a difficult access to plants because of the flooding and short harvest period, the fruit is often harvested green, what impairs the ascorbic acid content, despite being climacteric (Pinto et al. 2013). In contrast, when cultivated on dry land, camu-camu can produce more than one crop per year and thus be harvested at its optimum ripeness, coinciding with the highest ascorbic acid content (Yuyama \& Valente 2011).

Since camu-camu is naturally found both in low-acid soils and fertile floodplains of muddywater riverbanks and on less fertile acidic soils of black-water riverbanks, the fruit production and its respective contents, mainly ascorbic acid, may be variable (Hernández et al. 2011, Pinedo Panduro et al. 2011, Yuyama \& Valente 2011). It is important to highlight that this adaptation to different environments allows a better agronomic management of the species (Welter et al. 2011, Yuyama \& Valente 2011, Pinedo Panduro et al. 2018).

There is still no defined form of fertilization for the camu-camu production in non-flooded areas. Research on the growth of camu-camu seedlings in an Oxisol A horizon as substrate indicates that the plant demands little, regarding nutrients, and seedling growth is often better without any fertilization (Yuyama \& Valente 2011). On dry land, camu-camu has a satisfactory growth when fertilized with organic waste in the early years of planting, but the organic waste should be applied in small proportions or in parcels (Sousa 2009, Yuyama \& Valente 2011). Abanto-Rodríguez et al. (2014) found that $160 \mathrm{~kg} \mathrm{ha}^{-1}$ of potassium under a fertigation system provided better results, in relation to the height, diameter and number and total length of branches, as well as total mass and Dickson quality index, for the initial growth stage of camu-camu plants on dry land. In addition, Abanto-Rodríguez et al. (2018) evaluated the nutrients of camu-camu plants fertigated with nitrogen doses and found that doses greater than $128 \mathrm{~kg} \mathrm{ha}^{-1}$ cause a decrease in biomass in the initial growth stage of plants.

Camu-camu is an important source of vitamin $\mathrm{C}$ (ascorbic acid), whose content in the fruit is influenced by various factors, such as fruit ripeness, soil nutrients, flood level in its environment and fertilization (Chagas et al 2015, Aguiar \& Souza 2016, Grigio et al. 2016). In non-flooded environments, some researchers have found that camu-camu fertilization with $\mathrm{N}$ and $\mathrm{K}$ sources increased the ascorbic acid content in the fruits (Gavinho 2005, Abanto-Rodríguez et al. 2016).

In this context, this study aimed to evaluate fruit characteristics and ascorbic acid content of camu-camu under organic and mineral fertilization, by using sugarcane and guarana residues in the first years of planting, in a non-flooded area.

\section{MATERIAL AND METHODS}

The experiment was conducted during the months of January 2010 and January 2011, at the Usina Agropecuária Jayoro, in Presidente Figueiredo, Amazonas state, Brazil (01 ${ }^{\circ} 96^{\prime} 04^{\prime \prime}$ 'S and $60^{\circ} 14^{\prime} 37^{\prime \prime} \mathrm{W}$ ), where the climate is Afi, according to the Köppen classification, with an average annual temperature of $26.7{ }^{\circ} \mathrm{C}$, average annual rainfall of around $2,419 \mathrm{~mm}$ and average relative humidity of 88 \% (Carvalho \& Molinari 2014).

The soil in the area is an Oxisol, according to the American classification (Latossolo by the Brazilian soil classification system; Embrapa 2018), which is poor in nutrients and has a high depth and high water permeability (USA 2014).

The orchard, consisting of accessions from Uatumã, Iquitos and Roraima, was propagated using seeds obtained from the camu-camu germplasm bank of the Instituto Nacional de Pesquisas da Amazônia (INPA). These were randomly selected from high yield and high ascorbic acid matrices.

Organic fertilizers were added during the cultivation, consisting of byproducts of sugarcane (Saccharum officinarum) (filter cake and sugarcane bagasse) and guarana (Paullinia cupana) (seed husk). The compost fertilizer was a mixture of sugarcane bagasse ash, filter cake and guarana seed husk in equal proportions. The filter cake, made according to Sousa (2009), had the following chemical characteristics: $\mathrm{C}: 119.2 \mathrm{~g} \mathrm{~kg}^{-1}$; total N: $5.39 \mathrm{~g} \mathrm{~kg}^{-1}$; K: $3.3 \mathrm{mg} \mathrm{kg}^{-1}$; P: $547.4 \mathrm{mg} \mathrm{kg}^{-1}$; $\mathrm{Mg}$ : $206.7 \mathrm{mg} \mathrm{kg}^{-1}$; Fe: $3,455.0 \mathrm{mg} \mathrm{kg}^{-1}$; Zn: $44.0 \mathrm{mg} \mathrm{kg}^{-1}$; Mn: $349.0 \mathrm{mg} \mathrm{kg}^{-1}$. The chemical characteristics for the compost fertilizer were: $\mathrm{C}: 125.7 \mathrm{~g} \mathrm{~kg}^{-1}$; total $\mathrm{N}$ : $6.5 \mathrm{~g} \mathrm{~kg}^{-1}$; P: $1,150.0 \mathrm{mg} \mathrm{kg}^{-1} ; \mathrm{K}: 4,890.0 \mathrm{mg} \mathrm{kg}^{-1}$; $\mathrm{Ca}:$ $126.3 \mathrm{mg} \mathrm{kg}^{-1}$; Mg: $211.5 \mathrm{mg} \mathrm{kg}^{-1}$; Fe: $109.0 \mathrm{mg} \mathrm{kg}^{-1}$; $\mathrm{Zn}: 4.9 \mathrm{mg} \mathrm{kg}^{-1}$; Mn: $8.7 \mathrm{mg} \mathrm{kg}^{-1}$.

The experimental design was randomized blocks, with 10 treatments and 4 replications. Each experimental plot consisted of 4 lines with 5 holes ( 3 plants hole $\left.{ }^{-1}\right)$. Thus, each treatment was 
composed of 60 plants with $5 \mathrm{~m}$ between rows and $2 \mathrm{~m}$ between holes. The treatments were: 1) no fertilization; 2) filter cake ( $2 \mathrm{~L} \mathrm{hole}^{-1}$ ) every two months; 3 ) filter cake (2 $\left.\mathrm{L} \mathrm{hole}^{-1}\right)$ every four months; 4) compost ( $\left.2 \mathrm{~L} \mathrm{hole}^{-1}\right)$ every four months; 5) filter cake $\left(2 \mathrm{~L} \mathrm{hole}^{-1}\right)+$ compost $\left(2 \mathrm{~L} \mathrm{hole}^{-1}\right)$ every two months; 6) filter cake $\left(2 \mathrm{~L} \mathrm{hole}^{-1}\right)+$ compost $\left(2 \mathrm{~L} \mathrm{hole}^{-1}\right)$ every four months; 7) mineral (90-90-240 g/N-P $\mathrm{O}_{5}-\mathrm{K}_{2} \mathrm{O}$, corresponding to $200 \mathrm{~g}$ of urea, $500 \mathrm{~g}$ of triple superphosphate and $400 \mathrm{~g}$ of potassium chloride, divided into 3 applications) every four months; 8) mineral + filter cake ( L hole $\left.^{-1}\right)$ every four months; 9) mineral + compost $\left(\mathrm{L} \mathrm{hole}^{-1}\right)$ every four months; 10) mineral + filter cake + compost $\left(\mathrm{L} \mathrm{hole}^{-1}\right)$ every four months. Fertilization was performed manually at the base of the plant every year, for three years (April 2007 to December 2010). Leaf and soil samples were collected in April 2009 and May 2010, respectively. On these occasions, one soil sample was collected per plot, and was subsequently air-dried and sieved (2-mm mesh). The leaf analyses were performed by collecting leaf samples in the middle part of the canopy of five plants in each plot, and twenty leaves in total were collected from all the plots. These were dried in an oven at $65{ }^{\circ} \mathrm{C}$, for later analysis. The analysis of leaf and soil nutrient content followed the methods described and compiled by the Embrapa in 2009 and 2017, respectively.

For the yield analysis, fruits with more than $50 \%$ of red area (ripeness) were collected every 14 days, from March 2010 to January 2011. The evaluated variables were: fruit yield $\left(\mathrm{g} \mathrm{plant}^{-1}\right)$; number of fruitbearing plants (\%); average pulp weight plus skin (g); pulp yield plus skin (based on fruit and pulp; \%); fruit weight $(\mathrm{g})$, diameter and length $(\mathrm{cm})$.
Chemical analyses were performed in triplicate, and the following parameters were evaluated: $\mathrm{pH}$ (photometric method, Micronal pHmeter B474); soluble solids [refractometric method, Atago N-1E Brix Refractometer (0-32\% Brix)]; ascorbic acid content [extraction as oxalic acid $0.5 \%(\mathrm{~m} / \mathrm{v})$ ] and titration (2,6-dichlorophenolindophenol) (AOAC 1998).

The data were subjected to analysis of variance by the $\mathrm{F}$ test and means compared by the Tukey test at $5 \%$ of probability. A simple Pearson's correlation analysis at $5 \%$ of probability was also used between fruit yield and soil and leaf chemical characteristics. The data for pulp yield and number of fruit-bearing plants were transformed to arc sine of $\sqrt{ } \mathrm{x}+0.01$, for the analysis of variance.

\section{RESULTS AND DISCUSSION}

The chemical analysis of the camu-camu leaves showed no nutritional deficiency according to the different fertilization treatments (Tables 1 and 2). Viégas et al. (2004), in similar tests, found similar levels of macro and micronutrients in camu-camu leaves, also an indicative of no deficiency symptoms. It can be observed that, for the micronutrient $\mathrm{N}$, the majority of the treatments presented values greater than those found by Esashika et al. (2011) $\left(18.2 \mathrm{~g} \mathrm{~kg}^{-1}\right)$ and proportional to those observed by Abanto-Rodríguez et al. (2018) (22.8 g kg-1). On the other hand, the use of the compost every 4 months caused a lower $\mathrm{N}$ value in the leaves $\left(13.7 \mathrm{~g} \mathrm{~kg}^{-1}\right)$ (Table 1).

The measurements of the camu-camu fruit yield revealed variations between the different

Table 1. Leaf analysis of camu-camu macronutrients under organic and mineral fertilization.

\begin{tabular}{|c|c|c|c|c|c|c|}
\hline \multirow{2}{*}{ Fertilization } & $\mathrm{N}$ & $\mathrm{P}$ & $\mathrm{K}$ & $\mathrm{Ca}$ & $\mathrm{Mg}$ & $\mathrm{S}$ \\
\hline & \multicolumn{6}{|c|}{$\mathrm{g} \mathrm{kg}^{-1}$} \\
\hline No fertilization & 18.7 & 1.4 & 7.1 & 4.1 & 1.5 & 1.3 \\
\hline Filter cake every two months & 18.0 & 1.1 & 4.8 & 3.2 & 1.2 & 1.0 \\
\hline Filter cake every four months & 20.3 & 1.1 & 5.1 & 4.9 & 1.5 & 1.0 \\
\hline Compost $^{(1)}$ every four months & 13.7 & 1.3 & 5.5 & 4.5 & 1.5 & 1.2 \\
\hline Filter cake + compost every two months & 18.9 & 1.3 & 6.5 & 4.2 & 1.2 & 1.2 \\
\hline Filter cake + compost every four months & 16.9 & 1.1 & 4.7 & 3.7 & 1.5 & 0.9 \\
\hline Mineral $^{(2)}$ every four months & 22.4 & 1.6 & 8.4 & 4.3 & 1.3 & 1.5 \\
\hline Mineral + filter cake every four months & 20.0 & 1.3 & 6.8 & 5.0 & 1.2 & 1.3 \\
\hline Mineral + compost every four months & 21.0 & 1.6 & 8.0 & 3.7 & 1.2 & 1.2 \\
\hline Mineral + filter cake + compost every four months & 21.0 & 1.5 & 7.9 & 4.1 & 0.9 & 1.4 \\
\hline
\end{tabular}

${ }^{(1)}$ Mixture of sugarcane bagasse ash, filter cake and guarana seed husk in equal proportions; ${ }^{(2)} \mathrm{N}-\mathrm{P}_{2} \mathrm{O}_{5}-\mathrm{K}_{2} \mathrm{O}$. 
Table 2. Leaf analysis of camu-camu micronutrients under organic and mineral fertilization.

\begin{tabular}{|c|c|c|c|c|c|}
\hline Fertilization & $\mathrm{B}$ & $\mathrm{Cu}$ & $\begin{array}{c}\mathrm{Fe} \\
-\mathrm{mg} \mathrm{kg}^{-1}\end{array}$ & $\mathrm{Mn}$ & $\mathrm{Zn}$ \\
\hline No fertilization & 100.9 & 4.6 & 128.1 & 72.0 & 16.7 \\
\hline Filter cake every two months & 94.9 & 3.1 & 65.7 & 104.6 & 13.9 \\
\hline Filter cake every four months & 82.4 & 2.8 & 61.1 & 156.2 & 13.3 \\
\hline Compost $^{(1)}$ every four months & 78.5 & 4.6 & 65.5 & 117.2 & 14.9 \\
\hline Filter cake + compost every two months & 89.8 & 3.8 & 55.3 & 142.7 & 14.8 \\
\hline Filter cake + compost every four months & 50.5 & 2.3 & 64.4 & 179.4 & 12.5 \\
\hline Mineral $^{(2)}$ every four months & 65.7 & 6.0 & 68.6 & 134.4 & 21.0 \\
\hline Mineral + filter cake every four months & 106.6 & 3.5 & 56.1 & 388.8 & 17.4 \\
\hline Mineral + compost every four months & 32.9 & 4.4 & 82.2 & 185.4 & 19.4 \\
\hline Mineral + filter cake + compost every four months & 104.2 & 4.2 & 67.1 & 221.9 & 17.4 \\
\hline
\end{tabular}

${ }^{(1)}$ Mixture of sugarcane bagasse ash, filter cake and guarana seed husk in equal proportions; ${ }^{(2)} \mathrm{N}-\mathrm{P}_{2} \mathrm{O}_{5}-\mathrm{K}_{2} \mathrm{O}$.

types of mineral and organic fertilization. The fruit yield, number of fruit-bearing plants, and pulp and skin weight were higher when the plants received fertilizers with compost + filter cake than when under mineral and organic fertilization. However, the peeled pulp yield did not vary, when comparing mineral and organic fertilization (Table 3 ).

The highest fruit yield occurred in soils with $1.9 \mathrm{cmol}_{\mathrm{c}} \mathrm{dm}^{-3}$ and $1.0 \mathrm{cmol}_{\mathrm{c}} \mathrm{dm}^{-3}$ of exchangeable sum of base and $0.2 \mathrm{cmol}_{\mathrm{c}} \mathrm{dm}^{-3}$ and $1.0 \mathrm{cmol}_{\mathrm{c}} \mathrm{dm}^{-3}$ of Al content, which corresponded to filter cake fertilization every four months and filter cake + compost every four months, respectively (Table 4).

Viégas et al. (2004) indicate that camucamu requires little $\mathrm{Ca}$ and $\mathrm{Mg}$, what would partly explain the higher camu-camu fruit yield in low base saturation soils. On the other hand, the $\mathrm{Al}$ content found in the plots fertilized with compost + filter cake and filter cake every four months were similar to floodplains where camu-camu occurs naturally, justifying the higher fruit yield per plant in these treatments (Mafra et al. 2007, Fajardo et al. 2009, Yuyama \& Valente 2011).

Apparently, a rapid nutrient availability in the soil was detrimental to the camu-camu fruit production. The same behavior was also observed in camu-camu seedlings when there was a rapid change in the physical characteristics of the soil due to organic fertilization (Abanto-Rodríguez et al. 2018). Coincidentally, Sousa (2009), who studied camu-camu under the same conditions of this experiment, found that the camu-camu growth is more impaired by mineral fertilization than by organic fertilization in the first year of growing, and

Table 3. Fruit yield, number of fruit-bearing plants, average pulp + skin weight and pulp + skin yield under organic and mineral fertilization.

\begin{tabular}{|c|c|c|c|c|}
\hline Fertilization & $\begin{array}{l}\text { Fruit yield* } \\
\left(\text { g plant }^{-1}\right)\end{array}$ & $\begin{array}{c}\text { Number of fruit- } \\
\text { bearing plants* }(\%)\end{array}$ & $\begin{array}{l}\text { Average pulp }+ \\
\text { skin weight* }(\mathrm{g})\end{array}$ & $\begin{array}{l}\text { Pulp }+ \text { skin } \\
\text { yield }^{\text {ns }}(\%)\end{array}$ \\
\hline No fertilization & $61 \mathrm{ab}$ & $11 \mathrm{~d}$ & $5.72 \mathrm{ab}$ & 75.86 \\
\hline Filter cake every two months & $157 \mathrm{ab}$ & $30 \mathrm{abc}$ & $5.86 \mathrm{ab}$ & 76.00 \\
\hline Filter cake every four months & $274 \mathrm{a}$ & $34 \mathrm{ab}$ & $6.52 \mathrm{a}$ & 77.07 \\
\hline Compost $^{(1)}$ every four months & $152 \mathrm{ab}$ & $23 \mathrm{abcd}$ & $6.55 \mathrm{ab}$ & 73.59 \\
\hline Filter cake + compost every two months & $123 \mathrm{ab}$ & $36 \mathrm{a}$ & $5.55 \mathrm{ab}$ & 75.51 \\
\hline Filter cake + compost every four months & $288 \mathrm{a}$ & $36 \mathrm{a}$ & $6.92 \mathrm{a}$ & 77.67 \\
\hline Mineral $^{(2)}$ every four months & $26 \mathrm{~b}$ & $16 \mathrm{~cd}$ & $4.02 \mathrm{~b}$ & 71.78 \\
\hline Mineral + filter cake every four months & $12 \mathrm{ab}$ & 20 abcd & $4.73 \mathrm{~b}$ & 73.79 \\
\hline Mineral + compost every four months & $88 \mathrm{ab}$ & $29 \mathrm{abc}$ & $5.29 \mathrm{~b}$ & 75.03 \\
\hline Mineral + filter cake + compost every four months & $41 \mathrm{~b}$ & 19 bcd & $4.10 \mathrm{~b}$ & 72.06 \\
\hline
\end{tabular}

* Distinct lowercase letters in the columns for each variable differ from each other by the Tukey test at $5 \%$ of probability; ${ }^{\text {ns }}$ no significant difference. ${ }^{(1)}$ Mixture of sugarcane bagasse ash, filter cake and guarana seed husk in equal proportions; ${ }^{(2)} \mathrm{N}-\mathrm{P}_{2} \mathrm{O}_{5}-\mathrm{K}_{2} \mathrm{O}$. 
Table 4. Chemical analysis of soil under organic and mineral fertilization.

\begin{tabular}{|c|c|c|c|c|c|c|c|c|c|}
\hline Fertilization & $\begin{array}{c}\mathrm{pH} \\
\left(\mathrm{H}_{2} \mathrm{O}\right)\end{array}$ & $\begin{array}{c}\mathrm{C} \\
\mathrm{g} \mathrm{dm}^{-3}\end{array}$ & $\begin{array}{c}\mathrm{P} \\
-\mathrm{m}\end{array}$ & $\begin{array}{r}\mathrm{K} \\
\mathrm{m}^{-3}-\end{array}$ & $\mathrm{Ca}$ & $\mathrm{Mg}$ & $\begin{array}{c}\mathrm{Al} \\
\mathrm{cmol}_{\mathrm{c}} \mathrm{d}\end{array}$ & $\mathrm{H}+\mathrm{Al}$ & SB \\
\hline No fertilization & 4.8 & 18.8 & 24 & 97 & 0.5 & 0.3 & 0.4 & 8.9 & 1.1 \\
\hline Filter cake every two months & 5.2 & 23.2 & 31 & 121 & 1.5 & 0.3 & 0.1 & 8.5 & 2.2 \\
\hline Filter cake every four months & 5.1 & 25.0 & 25 & 77 & 1.4 & 0.3 & 0.2 & 8.9 & 1.9 \\
\hline Compost ${ }^{(1)}$ every four months & 4.7 & 24.4 & 7 & 35 & 0.6 & 0.3 & 0.7 & 11.1 & 1.0 \\
\hline Filter cake + compost every two months & 5.1 & 27.0 & 23 & 95 & 1.4 & 0.3 & 0.3 & 10.1 & 2.0 \\
\hline Filter cake + compost every four months & 4.0 & 23.8 & 92 & 290 & 0.6 & 0.2 & 1.0 & 13.2 & 1.6 \\
\hline Mineral $^{(2)}$ every four months & 4.4 & 19.7 & 141 & 530 & 0.8 & 0.2 & 0.5 & 12.0 & 2.4 \\
\hline Mineral + filter cake every four months & 4.9 & 22.6 & 138 & 54 & 1.2 & 0.2 & 0.2 & 11.4 & 1.6 \\
\hline Mineral + compost every four months & 5.2 & 25.6 & 22 & 58 & 1.6 & 0.5 & 0.1 & 9.7 & 2.3 \\
\hline Mineral + filter cake + compost every four months & 4.4 & 27.2 & 61 & 450 & 1.1 & 0.2 & 0.5 & 14.1 & 2.5 \\
\hline
\end{tabular}

(1) Mixture of sugarcane bagasse ash, filter cake and guarana seed husk in equal proportions; ${ }^{(2)} \mathrm{N}-\mathrm{P}_{2} \mathrm{O}_{5}-\mathrm{K}_{2} \mathrm{O}$.

this could have influenced the low fruit production in the experiment.

The yield for peeled pulp ranged from $71 \%$ to $77 \%$ of the total fruit weight (Table 2), what corroborates the results found by Yuyama \& Valente (2011) (73-86\%). The weight and size of the camucamu fruits showed a significant statistical difference under the distinct types of mineral and organic fertilization (Table 5). The average fruit weight, diameter and height were higher under fertilization with compost + filter cake every four months than when the plants were under a combined fertilization with mineral and organic substances (Table 5). The chemical parameters of the evaluated fruits showed no difference between the types of organic and mineral fertilization.

The $\mathrm{pH}$ and soluble solids ( $\left.{ }^{\circ} \mathrm{Brix}\right)$ content did not present significant differences between the treatments with mineral and organic fertilizer, in this experiment. The average soluble solids content was $6.81{ }^{\circ} \mathrm{Brix}$, and the fruits had an average $\mathrm{pH}$ of 2.56 (Table 5). Other authors have also observed values ranging from $6.8^{\circ} \mathrm{Brix}$ to $9{ }^{\circ} \mathrm{Brix}$ and $\mathrm{pH}$ ranging from 2.3 to 3.5 in camu-camu (Maeda et al. 2007, Yuyama \& Valente 2011).

The average ascorbic acid content did not show any significant difference, in relation to the treatments with mineral fertilizer and organic matter, with an average content of $1,993 \mathrm{mg} 100 \mathrm{~g}^{-1}$ of pulp. On the other hand, there were plots with average contents of 2,554 $\mathrm{mg}$ and 4,043 $\mathrm{mg}$ of ascorbic acid per $100 \mathrm{~g}^{-1}$ of pulp under fertilization with filter cake + compost and mineral + filter cake + compost, respectively (Figure 1).

The variation in the ascorbic acid levels within each plot is possibly due to the non-homogenization

Table 5. Average fruit weight, diameter and height, soluble solids and $\mathrm{pH}$ of camu-camu fruits under organic and mineral fertilization.

\begin{tabular}{|c|c|c|c|c|c|}
\hline Fertilization & $\begin{array}{c}\text { Fruit } \\
\text { weight* }(\mathrm{g})\end{array}$ & $\begin{array}{l}\text { Fruit diameter* } \\
\qquad(\mathrm{cm})\end{array}$ & $\begin{array}{l}\text { Fruit height* } \\
(\mathrm{cm})\end{array}$ & $\begin{array}{c}\text { Soluble } \\
\text { solids }^{\text {ns }}\left({ }^{\circ} \text { Brix }\right)\end{array}$ & $\mathrm{pH}^{\mathrm{ns}}$ \\
\hline No fertilization & $7.54 \mathrm{ab}$ & $2.32 \mathrm{ab}$ & $2.16 \mathrm{ab}$ & 7.27 & 2.55 \\
\hline Filter cake every two months & $7.71 \mathrm{ab}$ & $2.34 \mathrm{ab}$ & $2.17 \mathrm{ab}$ & 7.26 & 2.52 \\
\hline Filter cake every four months & $8.46 \mathrm{ab}$ & $2.42 \mathrm{ab}$ & $2.25 \mathrm{ab}$ & 6.68 & 2.51 \\
\hline Compost $^{(1)}$ every four months & $8.49 \mathrm{ab}$ & $2.42 \mathrm{ab}$ & $2.25 \mathrm{ab}$ & 6.08 & 2.55 \\
\hline Filter cake + compost every two months & $7.35 \mathrm{ab}$ & $2.30 \mathrm{ab}$ & $2.14 \mathrm{ab}$ & 6.80 & 2.49 \\
\hline Filter cake + compost every four months & $8.91 \mathrm{a}$ & $2.47 \mathrm{a}$ & $2.30 \mathrm{a}$ & 7.13 & 2.61 \\
\hline Mineral $^{(2)}$ every four months & $5.60 \mathrm{~b}$ & $2.11 \mathrm{~b}$ & $2.00 \mathrm{~b}$ & 6.79 & 2.59 \\
\hline Mineral + filter cake every four months & $6.41 \mathrm{~b}$ & $2.19 \mathrm{~b}$ & $2.04 \mathrm{~b}$ & 6.76 & 2.67 \\
\hline Mineral + compost every four months & $7.05 \mathrm{~b}$ & $2.26 \mathrm{ab}$ & $2.11 \mathrm{ab}$ & 6.05 & 2.56 \\
\hline Mineral + filter cake + compost every four months & $5.69 \mathrm{~b}$ & $2.11 \mathrm{~b}$ & $2.00 \mathrm{~b}$ & 7.24 & 2.62 \\
\hline Coefficient of variation $(\%)$ & 24.31 & 6.10 & 5.81 & 9.81 & 3.13 \\
\hline
\end{tabular}




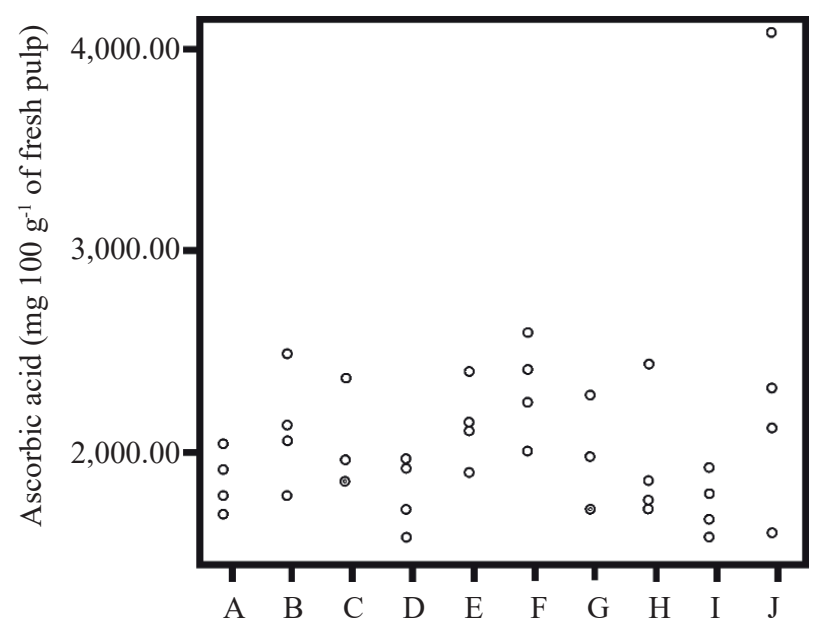

Figure 1. Ascorbic acid levels under organic and mineral fertilization: A) no fertilization; B) filter cake every two months; C) filter cake every four months; D) compost (mixture of sugarcane bagasse ash, filter cake and guarana seed husk in equal proportions) every four months; E) filter cake + compost every two months; F) filter cake + compost every four months; G) mineral (N-P $\left.\mathrm{O}_{5}-\mathrm{K}_{2} \mathrm{O}\right)$ every four months; $\mathrm{H}$ ) mineral + filter cake every four months; I) mineral + compost every four months; J) mineral + filter cake + compost every four months.

of the genetic material. On the other hand, this is the first report of a high content of ascorbic acid in orchards of camu-camu grown on upland areas. The study carried out found values of ascorbic acid ranging from 1,091 mg $100 \mathrm{~g}^{-1}$ to $3,465 \mathrm{mg} 100 \mathrm{~g}^{-1}$ of pulp (Yuyama \& Valente 2011). Since each plot was composed of 60 plants, an individual analysis of these could identify plants with even higher levels, which could be separated for later cloning.

\section{CONCLUSIONS}

Fertilization with compost (sugarcane bagasse ash, filter cake and guarana seed husk in equal proportions) + filter cake and only with filter cake, every four months, provide a higher fruit yield in camu-camu, while fertilization with filter cake + compost every four months increases the fruit average weight and size. Organic and mineral fertilization do not influence the $\mathrm{pH}$ or soluble solids of camucamu fruits. Ascorbic acid levels varied widely in the camu-camu samples analyzed, possibly due to the non-homogenization of the genetic material. Pulp and skin yield did not vary significantly under any type of fertilization, when compared to non-fertilized samples.

\section{REFERENCES}

ABANTO-RODRÍGUEZ, C.; ALVES-CHAGAS, E.; ALBUQUERQUE, T. C. S.; TADASHI-SAKAZAKI, R.; FARIAS-ARAÚJO, W.; SILVA-CHAVES, J. Early growth of camu-camu plants with nitrogen fertilization through fertirrigation. Scientia Agropecuaria, v. 7, n. 4, p. 367-376, 2016.

ABANTO-RODRÍGUEZ, C.; CHAGAS, E. A.; AlBUQUerQue, T. C.; SOUZA, A. das G.; ARAÚJO, W. F.; CHAGAS, P. C.; ANDRADE, J. K. C.; SOUZA, O. M. Early growth of camucamu plants under fertigation with potassium under solid ground conditions. Folia Amazónica, v. 23, n. 1, p. 7-16, 2014.

ABANTO-RODRÍGUEZ, C.; CHAGAS, E. A.; SIQUEIRA, R. H. S.; ARAÚJO, W. F.; ZBOROWSKI, L. G. C.; SOUZA, C. C. P.; SAKASAKI, R. T.; MONTEIRO NETO, J. L. L.; SÁNCHEZ-CHOY, J. Nutrient contents in camu-camu plants (Myrciaria dubia (Kunth) McVaugh) fertirrigated with different doses of nitrogen. Acta Agronomica, v. 67, n. 1, p. 79-87, 2018.

AGUIAR, J. P. L.; SOUZA, F. C. A. Camu-camu super fruit (Myrciaria dubia (H.B.K) Mc Vaugh) at different maturity stages. African Journal of Agricultural Research, v. 11, n. 28, p. 2519-2523, 2016.

ASSOCIATION OF OFFICIAL ANALYTICAL CHEMISTS (AOAC). AOAC peer-verified methods program: manual on policies and procedures. Gaithersburg: AOAC, 1998.

CARVALHO, D. P.; MOLINARI, D. C. Caracterization of the gullies of the BR 174 highway between Manaus and Presidente Figueiredo (AM). Revista Geografia Acadêmica, v. 8, n. 2, p. 5-19, 2014.

CHAGAS, E. A.; LOZANO, R. M. B.; CHAGAS, P. C.; BACELAR-LIMA, C. G.; GARCIA, M. R.; OLIVEIRA, J. V.; SOUZA, O. M.; MORAIS, B. S.; ARAÚJO, M. C. R. Intraspecific variability of camu-camu fruit in native populations of northern Amazonia. Crop Breeding and Applied Biotechnology, v. 15, n. 4, p. 265-271, 2015.

EMPRESA BRASILEIRA DE PESQUISA AGROPECUÁRIA (Embrapa). Centro Nacional de Pesquisa de Solo. Manual de análises químicas de solos, plantas e fertilizantes. 2. ed. Brasília, DF: Embrapa Produção de Informações, 2009.

EMPRESA BRASILEIRA DE PESQUISA AGROPECUÁRIA (Embrapa). Centro Nacional de Pesquisa de Solo. Sistema brasileiro de classificação de solos. 5. ed. Brasília, DF: Embrapa Produção de Informações, 2018. 
EMPRESA BRASILEIRA DE PESQUISA AGROPECUÁRIA(Embrapa). Centro Nacional de Pesquisa de Solos. Manual de métodos de análises de solo. 3. ed. Brasília, DF: Embrapa Produção de Informações, 2017.

ESASHIKA, T.; OLIVEIRA, L. A.; MOREIRA, F. W. Teores foliares de nutrientes em plantas de camucamuzeiro (Myrciaria dubia (H.B.K.) McVaugh) submetidas a adubações orgânica, mineral e foliar. Revista Brasileira de Ciências Agrárias, v. 6, n. 3, p. 391-400, 2011.

FAJARDO, J. D. V.; SOUZA, L. A. G.; ALFAIA, S. S. Características químicas de solos de várzea sob diferentes sistemas de uso da terra, na calha dos rios baixo Solimões e médio Amazonas. Acta Amazonica, v. 39 n. 4, p. 731740, 2009.

GAVINHO, C. A. Efeitos da adubação foliar na produção de frutos e na concentração de ácido ascórbico do camucamu (Myrciaria dubia) em condições de terra firme. 2005. Dissertação (Mestrado em Produção Vegetal) - Instituto Nacional de Pesquisas da Amazônia, Manaus, 2005.

GRIGIO, M. L.; CHAGAS, E. A.; DURIGAN, M. F. B.; SOUZA, A. A.; MOTA FILHO, A. B.; CHAGAS, P. C. Determination of harvest time and quality of native camucamu fruits (Myrciaria dubia (Kunth) Mc Vaugh) during storage. Fruits, v. 71, n. 6, p. 373-378, 2016.

HERNÁNDEZ, M. S.; CARRILLO, M.; BARRERA, J.; FERNÁNDEZ-TRUJILLO, J. P. Camu-camu (Myrciaria dubia Kunth Mc Vaugh). In: YAHIA, E. M. Postharvest biology and technology of tropical and subtropical fruits. Cambridge: Elsevier, 2011. p. 352-375.

MAEDA, R. N.; PANTOJA, L.; YUYAMA, L. K. O.; CHAAR, J. M. Estabilidade de ácido ascórbico e antocianinas em néctar de camu-camu (Myrciaria dubia (H. B. K.) McVaugh). Food Science and Technology, v. 27, n. 2, p. 313-316, 2007.

MAFRA, A. L.; SENESI, N.; BRUNETTI, G.; MIKLÓS, A. A. W.; MELFI, A. J. Humic acids from hydromorphic soils of the upper Negro river basin, Amazonas: chemical and spectroscopic characterisation. Geoderma, v. 138, n. 1-2, p. 170-176, 2007.

PENN JUNIOR, J. W. The cultivation of camu camu (Myrciaria dubia): a tree planting programme in the Peruvian Amazon. Forests, Trees and Livelihoods, v. 16, n. 1, p. 85-101, 2006.
PINEDO PANDURO, M.; ABANTO-RODRÍGUEZ, C.; OROCHE AMIAS, D.; PAREDES DÁVILA, E.; BARDALES-LOZANO, R. M.; CHAGAS, E. A.; MONTEIRO NETO, J. L. L.; VARGAS FASABI, J. Improvement of the agronomic characteristics and yield of camu-camu fruit with the use of biofertilizers in Loreto, Peru. Scientia Agropecuaria, v. 9, n. 4, p. 527-533, 2018.

PINEDO PANDURO, M.; DELGADO VÁSQUEZ, C.; FARROÑAI PERAMAS, R.; DEL CASTILLO TORRES, D.; IMÁN CORREA, S.; VILLACRES VALLEJO, J.; FACHÍN MALAVERRI, L.; OLIVA CRUZ, C.; ABANTO-RODRÍGUEZ, C.; BARDALES LOZANO, R.; VEGA VIZCARRA, R. Сати сати (Myrciaria dubia, Myrtaceae): aportes para su aprovechamiento sostenible en la Amazonía peruana. Iquitos: Instituto de Investigación de la Amazonía Peruana, 2011.

PINTO, P. M.; JACOMINO, A. P.; SILVA, S. R.;ANDRADE, C. A. W. Ponto de colheita e maturação de frutos de camu-camu colhidos em diferentes estágios. Pesquisa Agropecuária Brasileira, v. 48, n. 6, p. 605-612, 2013.

SOUSA, E. C. C. Uso de resíduos orgânicos e adubo mineral no cultivo de camucamuzeiro em terra firme no estado do Amazonas. 2009. Dissertação (Mestrado em Produção Vegetal) - Programa de Pós-graduação em Agricultura no Trópico Úmido, Instituto Nacional de Pesquisas da Amazônia, Manaus, 2009.

USA. Soil Survey Staff. Soil taxonomy: a basic system of soil classification for making and interpreting soil surveys. Washington, DC: United States Department of Agriculture, 2014.

VIÉGAS, I. J. M.; THOMAZ, M. A. A.; SILVA, J. F.; CONCEIÇÃO, H. E. O.; NAIFF, A. P. M. Efeito da omissão de macronutrientes e boro no crescimento, nos sintomas de deficiências nutricionais e na composição mineral de plantas de camucamuzeiro. Revista Brasileira de Fruticultura, v. 26, n. 2, p. 315-319, 2004.

WELTER, M. K.; MELO, V. F.; BRUCKNER, C. H.; GÓES, H. T. P.; CHAGAS, E. A.; UCHÔA, S. C. P. Effect of level of crushed balsat in the initial development of seedlings of camu-camu (Myrciaria dubia H.B.K. McVaugh). Revista Brasileira de Fruticultura, v. 33, n. 3, p. 922-931, 2011.

YUYAMA, K.; VALENTE, J. P. (org.). Сати-сатu: Myrciaria dubia (Kunth) McVaugh. Curitiba: CRV, 2011. 